\title{
The State Aid Instruments in Response to the COVID-19 Crisis
}

\author{
Paulina Kubera \\ Poznan University of Technology, J. Rychlewskiego 2, 60-965 Poznań, Poland, \\ Paulina.Kubera@put.poznan.pl
}

Received date: 3 September 2020; Accepted date: 6 January 2021; Published date: $1^{\text {st }}$ ferbruary 2021

Academic Editor: Anna Mempel-Śnieżyk

Copyright (C) 2021. Paulina Kubera. Distributed under Creative Commons Attribution 4.0 International CC-BY 4.0

\begin{abstract}
The COVID 19 outbreak has hit the global (including the EU) economy unexpectedly and with great force. Many so far healthy undertakings have had to face the looming lack of liquidity. In order to counter the damage inflicted on undertakings and to perverse the continuity of economic activity during and after the coronavirus pandemic, public authorities were forced to step in and launch various types of support measures for entrepreneurs. This has raised particular issues from the State aid regime perspective. The article seeks to answer the question what is the EU response to the coronavirus pandemic in terms of the revised state aid policy. To this end, it is discussed what types of public instruments for entrepreneurs constitute state aid and thus fall within the EU control; what concrete support measures for business are utilized by member states in these troubled times and what are the guiding principles in deciding on their approval by the European Commission. Considerations are based on literature review, the analysis of relevant legal provisions and guidelines as well as selected state aid cases related to coronavirus.
\end{abstract}

Keywords: State aid, COVID 19, public support for entrepreneurs

\section{Introduction}

The spread of the coronavirus hit the global economy unexpectedly and with great force. In response, countries around the world implemented several containment measures to halt the pandemic, including social distancing measures, travel restrictions and lock downs. These had a stifling effect on economic activities, not only in tourism, entertainment or transport sectors, but in

Cite this Article as: Paulina Kubera (2021)," The State Aid Instruments in Response to the COVID-19 Crisis", The Journal of Organizational Management Studies, Vol. 2021 (2021), Article ID 930488, 
almost all sectors, without sparing large enterprises. Moreover, uncertainty surrounding the near and distant future led to flight to safety in consumption and had a negative effect on investment plans. Many so far healthy undertakings have had to deal with the looming lack of liquidity.

In order to counter the damage inflicted on undertakings and to perverse the continuity of economic activity during and after the coronavirus pandemic, public authorities were forced to launch simultaneously various types of support measures for entrepreneurs.

The article examines how freely can EU member states design their interventions and what support measures for entrepreneurs are utilised to deal with the effects of the COVID-19. The problem is vital for the avoidance of harmful subsidy races among EU member states where those member states that have larger funds at their disposal can outspend neighbours to the detriment of cohesion within the EU. The level playing field in the EU internal market must be preserved. Considerations are based on literature review, the analysis of relevant legal provisions and guidelines as well as selected state aid cases related to coronavirus.

The remainder of the paper is structured as follows. The first part is devoted to the problem of the differentiation between state aid and general public measures that is crucial in determining the competences of $\mathrm{EU}$ member states to implement their own support measures. In the next sections, the notion of state aid is further clarified, its admissibility criteria are discussed in the context of coronavirus pandemic as well as relevant state aid cases are invoked for illustrative purposes. The article ends with final conclusions.

What is state aid and how does it differ from general public measures?
Generally, economic policy falls within the remit of each EU member state. Nevertheless, the process of economic policy coordination at the EU level takes place in either 'soft' as well as 'hard' forms. The former denote moral persuasion and peer pressure through benchmarking and exchange practices, the latter - strict rules to be respected with a sanction mechanism attached to them. The example of 'soft' coordination is the broad economic policy guidelines and employment guidelines, the example of the 'hard' cooperation is the stability and growth pact, a set of rules designed to ensure that member states pursue sound public finance. Currently, these coordination processes, reformed, work in parallel under the 'European Semester'. The European Semester brings together within a single policy coordination cycle many EU instruments. The EU institutions set priorities for the EU, review national performance, economic reform and budget plans and issue CountrySpecific Recommendations (CSRs). As Verdun and Zeitlin (2018) point out: 'Although the Semester involves no legal transfer of sovereignty from the member states to the EU level, it has given the EU institutions a more visible and authoritative role than ever before in monitoring, scrutinizing and guiding national economic, fiscal and social policies, especially within the euro area' (p.138). However, as the current economic downturn caused by the coronavirus outbreak is becoming a huge strain on the budgets of member states and the debt-to -GDP ratios are rising (see, for example: Dullien et al., 2020), the European Semester process will be temporarily modified in 2021. The economy of the European Union is expected to shrink by 7.4 percent in 2020 (in the euro area by 7.8\%), with Spain and the United Kingdom set to be the worst affected economies, seeing GDP decline by 12.4 percent and 10.3 percent respectively (the Autumn 2020 Forecast). Hence, the need to coordinate the European Semester with the Recovery and Resilience Facility, which consists of large-scale financial support to both investments and reforms undertaken by member states to

Paulina Kubera (2021), The Journal of Organizational Management Studies,

DOI: $10.5171 / 2021.930488$ 
mitigate the economic and social impact of the coronavirus pandemic and better prepare states for sustainable recovery. The change is that member states are to submit national reform programmes and recovery and resilience plans in a single integrated document. The European Commission will assess the substance of the recovery and resilience plans and these documents will substitute the European Semester country reports. Moreover, country specific recommendations will concern only the budgetary situation, which means that there will be no structural country-specific recommendations in 2021 for those member states that will have submitted recovery and resilience plans.

As most of the funds to ease the socioeconomic impact of the coronavirus pandemic are distributed by member states and their substantial part goes to undertakings, they should be considered from the point of view of State aid regime irrespective of their source - EU or national (see: next section on four criteria to establish state aid presence). Member states enjoy discretionary power in reference to the implementation of general public measures. Selectivity is a feature that differentiates state aid form general measures which are applicable to all undertakings in all sectors within the state (Sciskalová \& Münster, 2014). Shaping the tax system or social security system are examples of general public measures as long as they do not favour certain undertakings or the production of certain goods. Then they are not contradictory to the EU internal market and any possible distortions of the competition being their result are eliminated through the harmonisation of the law of member states and coordination of economic policies (Schütte, 2006; Kubera, 2011). State aid, in turn, implies granting an advantage in a selective way 'over other undertakings that are in a legal and factual situation that is comparable in the light of the objective pursued by the measure' (Case C-143/99 Adria-Wien Pipeline GMBH,
ECLI:EU:C:2001:598, par.41). Being a selective intervention in the market, state aid is under the EU control. According to Article 3 of TFUE: 'the establishing of competition rules necessary for the functioning of the internal market' lies within the exclusive competence of EU.

A word of caution must be mentioned here. The very fact that undertakings are treated differently in public policy instruments does not automatically imply the existence of state aid. As a matter of fact, general measures frequently differentiate between recipients of public interventions. When general measures incorporate detailed provisions applicable to certain undertakings only, they still can have their rationale in logic and nature of the system of which they are part (Case C-53/00 Ferring SA and ACOSS, EU:C:2001:627, par. 17). An example are special purpose levies such as environmental taxes which are imposed exactly to discourage some activities or the production of some products which are detrimental to the environment. Differentiation between undertakings derives directly from the intrinsic objective of the system (in this case this special-purpose levy). Other legitimate grounds for introducing a differentiation between undertakings in public policy measures may result from inherent mechanisms necessary for the functioning and effectiveness of the system, such as the need to avoid double taxation, to fight fraud or tax evasion. In any case, member states should ensure that those measures are proportionate and do not exceed what is necessary to achieve the objective being pursued, (see: Commission Notice on the notion of State aid as referred to in Article 107(1) of the TFUE).

It is also pertinent to stress that material selectivity can also be established de facto. When a state measure which appeared to be applied to undertakings in general way, i.e., its formal criteria are formulated in general and objective term, in reality produces an advantage for certain undertakings or the

Paulina Kubera (2021), The Journal of Organizational Management Studies,

DOI: $10.5171 / 2021.930488$ 
production of certain goods, to the exclusion of others, (see: joined Cases Ramondin SA and Ramondín Cápsulas SA v Commission, T 92/00 and T-103/00, ECLI:EU:T:2002:61, par. 39). Moreover, selectivity can stem from discretionary power of member states, where fulfilling the eligibility criteria of a given measure does not automatically result in an entitlement to the measure (see more: Kociubiński 2012).

To sum up, three main conclusions can be drawn from the above discussion. First, the adoption of general public measures which are applied to all undertakings in all sectors within a state falls within the competence of member states. What is under the Union control are selective public measures that can have an impact on competition and trade exchange between member states. Secondly, general measures frequently involve differentiation between economic actors making the assessment of a given public measure more challenging. In such a case, selectivity of the measure can be established de jure and de facto. The former (de jure) results directly from the legal criteria for granting a measure that is formally reserved only for certain undertakings, e.g., those having a certain size, operating in certain sectors, having certain characteristics or exercising certain functions. The latter (de facto) refers to situations where seemingly neutral and objective criteria for granting a measure in practice privilege certain undertakings or the production of certain goods. Thus, a measure should be considered selective also on the basis of its effects. Thirdly, even when selectivity of a public measure is established it does not automatically mean that this measure constitutes state aid. When there is justification for the selectivity in logic and nature of the system of which they are part, or the selectivity is the result of inherent mechanisms necessary for the functioning and effectiveness of the system (e.g., a corporate tax system), a measure falls outside the state aid rules.

\section{Admissibility criteria for state aid granting in the context of coronavirus}

In the previous section, the selectivity feature of state aid has been discussed to distinguish state aid from general public measures, what is crucial in determining the competences of EU member states to implement their own support measures. However, there are four criteria that must be met cumulatively for a measure to be qualified as state aid. Apart from being selective, these are:

- the measure must be financed through state resources and be imputable to the state; however, state resources are interpreted widely. They include, for example, EU funds distributed through national operational programmes. Therefore, the funds can come from the EU budget, provided that they are at the disposal of the member state at the moment of their transfer to the final beneficiaries. Moreover, state imputability does not imply that the decision concerning support granting has to be made by the state authorities. It can be made by any public or private entity provided that the state can exercise a decisive influence over it through organic links, instructions or close supervision (Bouchagiar 2020, Fanøe 2018),

- it must confer an economic advantage on its recipient (which an undertaking could not get under normal market condition) (see more: Cyndecka 2016), as well as

- the measure must distort or threaten to distort competition and affect trade between member states. However, an undertaking itself does not have to be involved in intra-Union trade, it suffices that aid helps to maintain or increase domestic activity, with the result that undertakings from other EU member states have less chance of penetrating the market of the member state concerned (Article 107(1) TFUE).

Paulina Kubera (2021), The Journal of Organizational Management Studies,

DOI: $10.5171 / 2021.930488$ 
It suffices that one of the above-specified criteria is not fulfilled to escape the state aid rules. The rationale for the EU state aid control stems from the fact that it is perceived as a mechanism which underpins the functioning of the internal market and supports economic integration (Kubera, 2020).

State aid is generally incompatible with the EU internal market and is admissible only under the conditions stipulated in EU law. However, the extraordinary times call for extraordinary measures. Therefore, in order to introduce more flexibility and speed up state aid decisions related to coronavirus, the Commission has issued Temporary framework for state aid measures to support the economy in the current COVID-19 outbreak which has been already revised several times. As Honoré (2020) describes it aptly: "The number of decisions and the decision time of the Commission are breathtaking and unprecedented... [that is way] ...commentators have been describing the process as 'constructing the railway with the train already on it' (p. 111).

The Temporary Framework indicates six support measures to tackle liquidity problems of undertakings that can be relied upon by member states. However, two of them do not qualify as state aid. These are:

1) measures that apply to all undertakings such as general wage subsidies, suspension of payments of corporate and value added taxes or social contributions that apply to all undertakings. These measures do not constitute state aid since they do not confer a selective advantage;

2) financial support provided directly to consumers, such as for cancelled services or tickets not reimbursed by the operators concerned. These measures do not constitute state aid since they do not confer an advantage on undertakings.
The next group of support measures can be implemented by member states also without the involvement of the European Commission, and this group encompasses:

3) measures designed in line with Block Exemption Regulation (i.e., Commission Regulation (EU) No $651 / 2014$ of 17 June 2014 declaring certain categories of aid compatible with the internal market in application of Articles 107 and 108 of the Treaty). They constitute state aid, however, since they are less likely to lead to undue distortions of competition in the EU internal market due to the limited amount and rules on which aid is granted, do not have to be notified to the Commission.

The remaining three qualify as state aid and will be discussed more in detail in the further sections of the article. These are:

(4) rescue and restructuring aid (Article 107(3)(c) TFEU)

(5) aid to make good the damage caused by exceptional occurrences (Article 107(2)(b) TFUE)

(6) aid to remedy a serious disturbance in the economy of a member state (Article 107(3)(b) TFUE)

\section{Rescue and restructuring aid (Article $107(3)$ (c) TFEU)}

According to Article 107(3)(c) TFUE, state aid may be granted to facilitate the development of certain economic activities or of certain economic areas, provided that such aid does not adversely affect trading conditions to an extent contrary to the common interest. This group encompasses support measures which are developed to meet acute liquidity needs and to support undertakings that face financial difficulties

Paulina Kubera (2021), The Journal of Organizational Management Studies,

DOI: $10.5171 / 2021.930488$ 
including those caused and aggravated by the coronavirus outbreak. However, these need to be in line with the strict criteria set out in the Rescue and Restructuring Guidelines (i.e., Communication from the Commission: Guidelines on State aid for rescuing and restructuring non-financial undertakings in difficulty 2014/C 249/01), in particular the principle 'one time last time', which means that aid can be granted to undertakings in difficulty in respect of only one restructuring operation. Moreover, it must be shown that the aid is truly in the public interest in a given case, in the sense that saving the undertaking would prevent social hardship or address market failures. The exit of firms and their replacement by others is not only a natural market process but also an important driver of productivity. Therefore, public interventions that interfere with that process are under particular EU scrutiny (MaierRigaud \& Milde, 2015).

Rescue aid is designed to allow undertakings which face imminent collapse to stay in business for long enough to develop a restructuring plan. It takes the form of liquidity support (loans or guarantees) and has a maximum duration of six months. When further support is needed, restructuring aid can be granted which aims at supporting a firm's restructuring and its return to long-term viability. Member states are free to choose the form that restructuring aid takes as well as it can be granted for a longer period of time, nevertheless the aid must be accompanied by a detailed restructuring plan that meets a number of conditions (the Competition DirectorateGeneral of the European Commission, 2014).

This was the case with a public guarantee on a loan in favour of Romanian airline BlueAir. The measure was divided into two parts and assessed under two different legal bases. In part (EUR 28 million), it was designed to compensate the airline for the damages suffered as a result of the coronavirus outbreak (assessment was carried out on the basis of Article 107(2)(b), which will be discussed in a subsequent section), and partially (EUR 34 million), to provide it with the necessary resources to address part of its urgent and immediate liquidity needs (assessment on the basis of the Rescue and Restructuring Guidelines). What is important, Blue Air was qualified as a company in difficulty before the coronavirus outbreak, i.e., on 31 December 2019. The Rescue and Restructuring Guidelines enable member states to support such undertakings, where the pandemic worsened the situation of a given undertaking that was already poor before the outbreak. The airline was loss making due to the extensive investments it undertook since 2016 to improve its network of routes. The airline had returned to profitability in 2019 and early 2020, however, as other undertakings active in the aviation sector, it suffered significant losses as a result of the coronavirus outbreak and the travel restrictions that Romania and other governments had to impose to limit the spread of the virus. As a result, the airlines suffered urgent liquidity needs. The Commission approved the rescue aid since it was limited in time and scope and its contribution to an objective of common interest was satisfactorily demonstrated. Romania committed to ensure that, after six months, the public guarantee will be terminated, or BlueAir will either submit a liquidation plan or carry out a through restructuring to become viable in the longterm (subject to the Commission's separate approval) and that aid is necessary to ensure regional connectivity for the significant number of citizens working abroad and for small local businesses that depend on affordable tickets offered by BlueAir on a network of routes it operates, (SA.57026 Romania, COVID-19 - Aid to Blue Air).

\section{Aid to make good the damage caused by exceptional occurrences (Article 107 (2) (b) TFUE)}

According to Article 107 (2) (b) TFUE, state aid which is granted to redress the damage caused by natural disasters or other exceptional occurrences is exempted from the general prohibition of state aid. However, 
for the sake of legal certainty, member states can notify such aid to the European Commission, which apart from the classification of the event as a natural disaster or another extraordinary event, takes into account the following when assessing a given aid measure with respect to it being compatible with the requirements stipulated in Article 107 (2) (b) TFUE: (1) proof of a direct relation between the damage and natural disaster or other extraordinary event, (2) proper assessment of damage, and (3) whether any mechanism to avoid excessive compensation has been introduced. It must be emphasised that only aid, which is aimed at the restoration of the condition prior to the natural disaster or other extraordinary event, is compatible with internal market.

On the basis of Article 107(2)(b) TFUE, member states can provide support for undertakings in sectors that have been particularly hit by the coronavirus pandemic, such as tourism, transport, hospitality or culture, as well as organisers of cancelled events for damages suffered due to and directly caused by the outbreak, e.g. part of the aid granted to previously mentioned BlueAir to compensate the damage directly caused by the coronavirus outbreak and the travel restrictions imposed by public authorities.

Another example is the Danish compensation scheme for cancellation of events related to COVID-19. On 6 March 2020, Danish authorities made an official recommendation that all public events with more than 1000 participants as well as those events which were targeted at COVID-19, vulnerable and high-risk groups (e.g., elderly), irrespective of the number of participants, be cancelled, postponed, or substantially modified. The subsequent losses and additional costs suffered by the organisers of such events resulted from the implementation of this recommendation could be compensated from state budget. The Commission has found a EUR 12 million Danish aid scheme to be in line with EU state aid rules. The Commission considers that the COVID-19 outbreak qualifies as an exceptional occurrence, referred to in Article 107(2)(b) TFUE, as it is an extraordinary, unforeseeable event having a significant economic impact. It clearly distinguishes itself from ordinary events by its character and by its effects on the affected undertakings and the economy in general and thus lays outside of the normal functioning of the market, (Commission decision SA. 56685, Denmark Compensation scheme for cancellation of events related to COVID-19).

\section{Aid to remedy a serious disturbance in the economy of a member state (Article 107(3)(b) TFUE)}

As the above stipulated option (based on Article 107(2)(b) TFUE) is restricted to compensation for damage directly caused by the coronavirus outbreak (e.g. damage suffered by the organisers of cancelled events, damage suffered by an airline caused by travel restrictions), aid addressing more generally the economic downturn from the coronavirus pandemic is assessed on the basis of Article 107(3)(b) TFUE, according to which aid to promote the execution of an important project of common European interest or to remedy a serious disturbance in the economy of a member state can be considered to be compatible with the internal market. Member states can invoke this ground for support measures granted for a limited period to remedy the liquidity shortage faced by undertakings that were not in difficulty on 31 December 2019 and to ensure that the disruptions caused by the coronavirus outbreak do not undermine their viability, in particular that of small and medium sized enterprises.

The Temporary Framework provides more detailed guidance on admissibility of the aid granted by a member state to remedy a serious disturbance in its economy. According to it, when aid is granted in the form of direct grants, tax and payment

Paulina Kubera (2021), The Journal of Organizational Management Studies,

DOI: $10.5171 / 2021.930488$ 
advantages, the Commission considers this type of aid to be compatible with the internal market if it meets the following conditions: (1) the total nominal value of such measure does not exceed EUR 800,000 per undertaking, (2) the aid is granted on the basis of a scheme with an estimated budget, (3) the aid is granted no later than 30 June 2021, (special rules apply to the agricultural, fisheries and aquacultural sectors and undertakings active in the processing and marketing of agricultural products). Secondly, when aid is granted in the form of new public guarantees on individual loans in response to the COVID-19 outbreak, the Commission considers this type of aid be compatible with the internal market if: (1) the guarantee premiums are set at a minimum level, as defined in the Temporary Framework, (2) the guarantee is granted by 30 June 2021 at the latest, (3) for loans with a maturity beyond 30 June, the amount of loans per undertaking does not exceed double the 2019 annual wage bill of the undertaking, or $25 \%$ of its total 2019 turnover; (the amount of the loan may be higher in justified cases and for loans with a maturity date until 30 June 2021), (4) the duration of the guarantee is limited to maximum six years and the public guarantee does not exceed: $90 \%$ of the loan principal where losses are sustained proportionally and under the same conditions, by the credit institution and the state, or $35 \%$ of the loan principal, where losses are first attributed to the state and only then to credit institutions; in both cases the guaranteed amount must decrease proportionally with the size of the loan as it starts to be reimbursed; (5) the guarantee relates to investment and/or working capital loans. Thirdly, aid can also be granted in the form of subsidised interest rates for loans. In that case the reduced interest rates should be at least equal to the base rate (1 year IBOR) plus a credit risk margin as specified in the Temporary Framework. Additional conditions are set where aid in the form of guarantees and loans is channeled through credit institutions or other financial institutions. Moreover, in the context of coronavirus, the Temporary
Framework makes public short-term export credit insurance more widely available until 30 June 2021.

A good example is a Danish aid scheme for the self-employed. First, the scheme was developed to compensate self-employed undertakings for losses of revenues caused by temporary prohibitions and implementation of recommendations issued by Danish authorities trying to contain the spread of the coronavirus, and as such the aid scheme was assessed on the basis of Article 107(2)(b) TFUE (aid to make good the damage caused by exceptional occurrences). However, along with the progressive reopening of the Danish economy and partial lifting of prohibitions and recommendations, the aid scheme has been amended as the main purpose of the measure changed from initial compensation scheme to direct grant scheme to mitigate liquidity problems for the undertakings concerned. Therefore, the compatibility assessment of the modified aid scheme was based on Article 107(3)(b) (aid to remedy a serious disturbance in the economy of a member state) and found compatible with the internal market since all the conditions set in the Temporary Framework (and specified above) were met. What is worth mentioning, the rule is that from this type of support measures cannot benefit undertakings that were already in difficulty on 31 December 2019. However, the exemption applies to micro and small enterprises provided that those enterprises, at the moment of granting the aid, are not subject to collective insolvency procedure under national law and they have not received rescue aid or restructuring aid. Thus, the Danish grant scheme has been made available for those undertakings, (SA.57919 (2020/N) Denmark. COVID-19: limited amounts of aid scheme for the selfemployed).

Another example is the Italian scheme to support undertakings active in the congress and fair industry affected by the coronavirus outbreak (SA 59992). The scheme is addressed to fair agencies and organisers of

Paulina Kubera (2021), The Journal of Organizational Management Studies,

DOI: $10.5171 / 2021.930488$ 
conventions and trade shows along with providers of logistics, transport and stand builders with more than $50 \%$ of turnover deriving from trade shows and conventions. The support has a form of a direct grant and is calculated as a proportion of the reduction in revenues suffered by an undertaking from 23 February 2020 to 31 July 2020, compared to the same period in 2019. The Commission has approved the scheme as there is a direct link between the worse financial situation of a beneficiary and the COVID 19 outbreak, and three basic requirements set in the Temporary Framework were met: the maximum amount of aid per undertaking is persevered (up to 800 euro), aid is to be granted on the basis of the scheme with an estimated budget and no later than 30 June 2021.

\section{Conclusions}

State aid has always been thought as the 'second best' option, meaning that member states may resort to state aid only when other less distortive policy measures, such as general and regulatory measures, cannot be applied instead to achieve a given objective. For instance, deferrals of payments of taxes and social security contributions could be a valuable tool to reduce the liquidity constrains of undertakings. When applied generally (i.e., are not restricted to certain undertakings, regions, sectors etc.), they fall outside state aid rules. Member states can also grant compensation for damage suffered due to and directly caused by the coronavirus outbreak for undertakings particularly impacted by the pandemic, such as transport, tourism or hospitality. Operating aid, which now is flowing in a wide stream as a response to the coronavirus crisis, has been repeatedly considered by the European Commission and EU courts as being distortive for competition 'in principle' since it keeps undertakings artificially afloat by covering costs they should cover themselves. Such aid can only be regarded as compatible with the EU internal market when it is granted on a temporary basis and is digressive, (with certain exemptions applied to remote regions), (Nicolaides, 2008).

The current coronavirus crisis seriously affected the economic situations of many so far healthy undertakings and their employees. Against this backdrop, there are no doubts that state aid is necessary to compensate the economic losses inflicted upon undertakings impacted by the pandemic and ensure that sufficient liquidity remains available in the market. Everything indicates that the total amount of state aid granted in response to the coronavirus outbreak, in particular in Western countries, will be at levels exceeding those of all previous crises (Kraus et al., 2020). However, in order to preserve European unity, state aid measures should not go beyond what is needed to preserve the continuity of economic activity during and after the outbreak. It can be argued that the Temporary framework for state aid measures to support the economy in the current COVID-19 outbreak does not undermine the fundamental rules of state aid granting. Member states are not free in designing their support measures which constitute state aid. The temporary framework sets limits on state aid, establishes the temporary nature of those instruments and does not lose sight of the aid effectiveness considerations. For instance, undertakings which were already in difficulty by 31 December 2019, i.e., before the crisis, cannot benefit from most of the measures (only to rescue and restructuring aid, however, exemptions apply to micro and small enterprises, see: above). Moreover, the overall amount of temporary state aid measures cannot exceed EUR 800000 per undertaking, what is important in situations when aid from different sources is cumulated, (different limits apply to the agriculture, fishery and aquaculture sectors). Finally, the Commission has made it imperative that aid cannot be conditioned on the relocation of the beneficiary's activity from one country within the European Economic Area to the member state granting

Paulina Kubera (2021), The Journal of Organizational Management Studies,

DOI: $10.5171 / 2021.930488$ 
the aid, since such a condition would be particularly harmful for the internal market.

While state aid addressing a lack of liquidity is certainly justified, not all member states are able to support their undertakings at the same level creating the risk of market distortions. In this context, the establishment of the EU-wide fund offering such liquidity interventions may be worth considering (see: Motta \& Peitz, 2020). Moreover, as the focus of this article is placed on short-run liquidity support measures that may not be enough, the next step could be to examine what measures states can take to support

\section{References}

- Bouchagiar, A. (2020), 'When Do Funds Become State Resources. The Notion of Aid in View of the Recent EEG and Achema Judgments'. European State Aid Law Quarterly 19(1), 19-28.

- Commission Notice on the notion of State aid as referred to in Article 107(1) of the TFUE (2016/C 262/01).

- Communication from the Commission (2020). Temporary framework for State aid measures to support the economy in the current COVID-19 outbreak the right incentives for innovation and growth.

- Competition Directorate-General of the European Commission (2014), 'New rules on rescue and restructuring aid for industry: the right incentives for innovation and growth', Competition policy brief, Issue 9

- Cyndecka, M. (2016), 'The Market Economy Investor Test in EU State Aid Law: Applicability and Application' ,Wolters Kluwers.

- Dullien, S., Paetz, C., Watt, A. and Watzka, S. (2020), 'Proposals for a reform of the EU's fiscal rules and economic governance', IMK Report 159e, June 2020.

- Fanøe, C. (2018), 'Award of Public Contracts as a Means to Conferring State Aid: A Legal Analysis of the Interface Between Public Procurement Law and entrepreneurs in the longer time perspective in their path towards objectives of common interest.

\section{Notes}

The definition of an undertaking in difficulty can be found in Art. 2, para. 18, of Commission Regulation (EU) 651/2014 of 17 June 2014 declaring certain categories of aid compatible with the internal market in application of Articles 107 and 108 of the Treaty (General Block Exemption Regulation).

State Aid Law, PhD Series, No. 10.2018, ISBN 9788793579675, Copenhagen Business School (CBS), Frederiksberg.

- Honoré, M. (2020), 'State Aid and COVID19 - Hot Topics', European State Aid Law Quarterly 19(2), 111-114.

- Kociubiński, J. (2012), 'Selectivity Criterion in State aid Control', Wroclaw Review of Law, Administration \& Economics 2(1), 1-15.

- Kraus, S., Clauss, T., Breier, M., Gast, J., Zardini, A. and Tiberius, V. (2020), 'The economics of COVID-19: initial empirical evidence on how family firms in five European countries cope with the corona crisis', International Journal of Entrepreneurial Behavior \& Research 26(5), 1067-1092.

- Kubera, P. (2011), The Union Control of State Aid in the Context of the EU Funds Implementation. Publishing House of Poznan University of Technology, Poznań

- Maier-Rigaud, F. and Milde, F. (2015), 'The Rescue and Restructuring Aid Guidelines of the European Commission: An Economic Point of View', World Competition 38(2), 189-213.

- Motta, M. and Peitz, M. (2020), EU State policies in the time of COVID-19, Europe in the Time of Covid-19, Bénassy-Quéré, A. and Weder di Mauro, B. (eds.). CEPR Press, 73-77.

- Nicolaides, P. (2008), 'Incentive Effect: Is State Aid Necessary when Investment Is

Paulina Kubera (2021), The Journal of Organizational Management Studies, DOI: $10.5171 / 2021.930488$ 
Unnecessary?' European State Aid Law Quarterly 7(2), 230-238.

- Schütte, M. (2006), The Notion of State Aid, The EC State Aid Regime: Distortive Effects of State Aid on Competition and Trade, Sánchez-Rydelski M.(ed.), Cameron May, London.

- Sciskalová, M. and Münster, M. (2014), 'Definition and characteristics of state aid', Procedia - Social and Behavioural Sciences 110, 223-230.

- Szyszczak E. (2016), Criterion of State Origin, State aid Law of the European Union, H.Hofmann and C.Micheau (eds.), Oxford University Press.
- Verdun, A. and Zeitlin, J. (2018), 'Introduction: the European Semester as a new architecture of EU socioeconomic governance in theory and practice in some cases by possible financial sanctions', Journal of European Public Policy 25(2), 137-148.

- European Economic Forecast. Autumn 2020. European Economy Paper 136. November 2020 (available at: https://ec.europa.eu/info/sites/info/file s/economy-finance/ip136_en_2.pdf)

Paulina Kubera (2021), The Journal of Organizational Management Studies, 